\title{
Polish Pleistocene stratigraphy - A review of interglacial stratotypes
}

\section{A. Ber}

Polish Geological Institute, 00-975 Warsaw, Rakowiecka 4 Str., Poland. Email: andrzej.ber@pgi.gov.pl

Manuscript received: February 2004; accepted: January 2005

\begin{abstract}
The Pleistocene stratigraphy of Poland is based on palynological analyses of buried organic lake sediments and dating with radiocarbon or thermoluminescence (TL), as well as on the lithologic-petrographical analyses of tills and other glacigenic deposits to which TL-dating was also applied. Rarely were sediments of the stratotype interglacial profiles to which palaeomagnetic methods and TL-dating were applied, examined by mineralogical, chemical and isotopic $\delta^{18} 0$ and $\delta^{13} \mathrm{C}$ analyses, except the Augustovian, Mazovian and Eemian interglacials. The data was recorded in both exposures and boreholes. Overall, tills of 8 glaciations have been identified: Narevian (Menapian), Nidanian, Sanian 1 (Elsterian 1), Sanian 2 (Elsterian 2), Liviecian (Fuhne), Krznanian (Drenthe), Wartanian (Warthe) and Vistulian (Weichselian). Substantial palynological evidence with complete pollen sequences and absolute dating exists for organic sediments of five interglacials: Augustovian (Bavelian Complex or Cromerian I), Ferdynandovian (Voigtstedt), Mazovian (Holstein), Zbójnian (Dömnitz) and Eemian. Other interglacials, i.e. Malopolanian (Cromer Complex - II or III Interglacial) and Lubavian (Schöningen) are not sufficiently supported palynologically and especially the stratigraphic position and age of the Lubavian Interglacial is debated.
\end{abstract}

Keywords: Poland, Pleistocene stratigraphy, palynological analyses, absolute dating, interglacial sediments

\section{Introduction}

This paper aims to provide an overview on recent advances in the Pleistocene stratigraphy of Poland and especially focuses on interglacial stratotypes sections. Some of them are described in detail, such as e.g. the Augustovian, the newly discovered and recently investigated interglacial, however others are described in general terms and their descriptions are based on earlier publications. This report does not concern interstadial periods. An interglacial, according to the definition of Fairbridge (1972), is understood as a geological time interval during which basic features of atmospheric and oceanic circulation were similar to those of recent times, and the climate was at least as warm as in the Holocene. Interstadial periods have considerably cooler climatic optima than interglacials and are devoid of thermophilic floristic elements. This report does not describe all the important interglacial sites with lacustrine organic deposits. Only the most well-known ones were selected for description, and those with well recognized geological setting and a set of geological investigations allowing for age and climate interpretations.

\section{Pleistocene history in Poland}

The territory of Poland consists of two types of glacial landscapes: flat and gently sloping surfaces in the south within areas that were occupied by the older glaciations, and flat, undulated and hummocky surfaces of outwash plains, end moraines, kames and eskers in the north, cut through by subglacial channels and lakes, within the limits of the Vistulian (Weichselian) Glaciation. In Poland, 8 to 11 glacial beds have been identified. Based on geological and lithologicpetrographical evidence, they are presumably represented by tills of 8 glaciations (Narevian, Nidanian, Sanian 1, Sanian 2, 


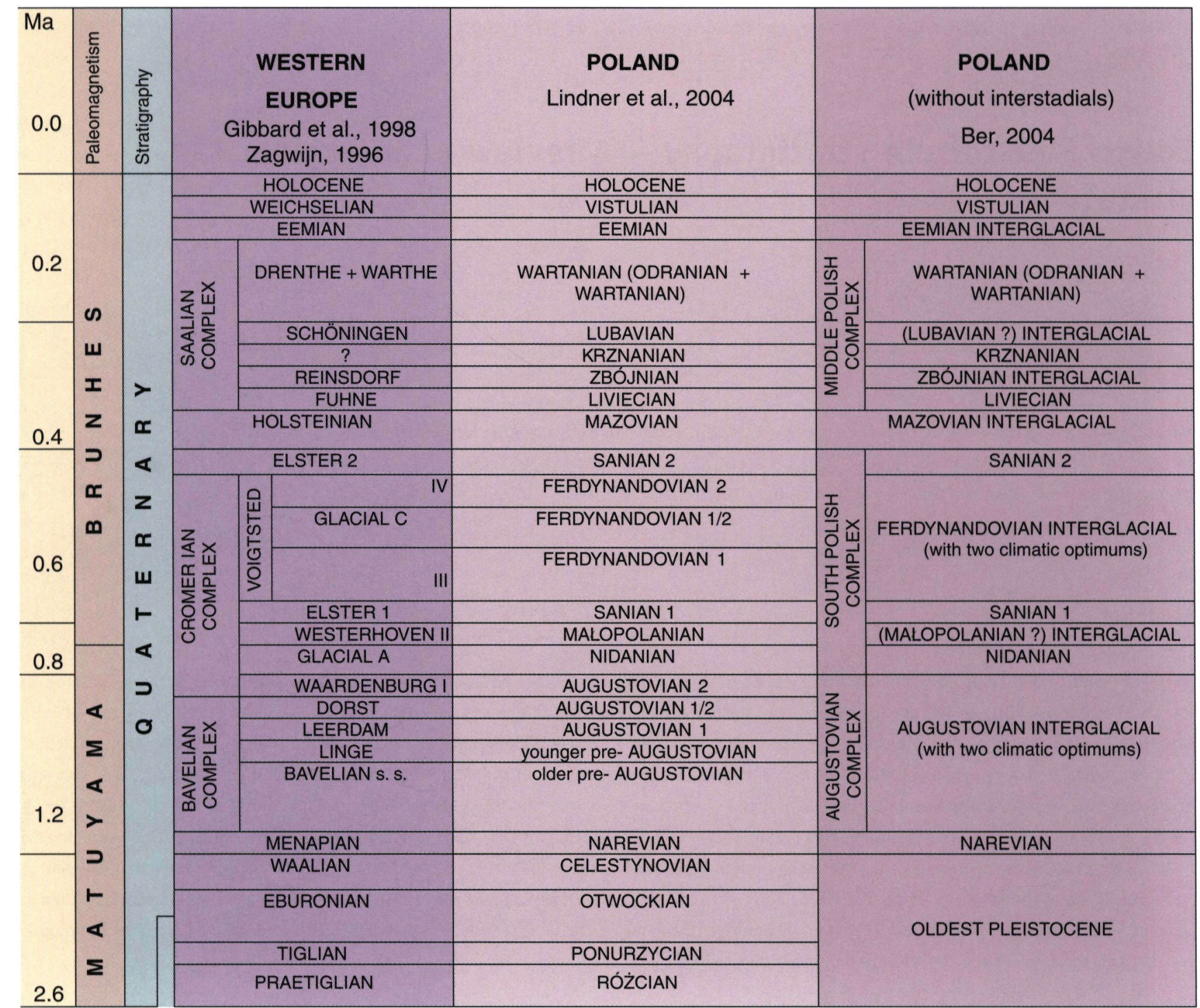

Fig. 1. Scheme of the Polish Quaternary stratigraphy.

Liviecian, Krznanian, Wartanian and Vistulian) (Lindner et al., 2004) and several stadials (Fig. 1). Their extents are shown on Fig. 2. However, petrographic analysis in the Vistula drainage basin and its vicinity indicates 16 stratigraphical till beds representing 8 glaciations and 15 stadials (Lisicki, 2003a,b). This number maybe overestimated because petrographic analysis of tills should be considered an auxilliary stratigraphic tool only. The lithostratigraphy of the till horizons in Poland has been established mainly on the basis of petrographical studies of the gravel fraction (5 - $10 \mathrm{~mm}$ in diameter) (Kenig, 2003; Lisicki, $2003 a, b)$ and the analysis of Scandinavian erratics (Górska, 2003; Zabielski, 1996). Another problem is the application of the thermoluminescence (TL) method to dating of these till beds.

Overall, stratotype sections of seven interglacials: Augustovian (Bavelian Complex or Cromerian I), Malopolanian (Cromer Complex II or III Interglacial), Ferdynandovian (Voigtstedt), Mazovian (Holstein), Zbójnian (Dömnitz), Lubavian (Schöningen) and Eemian and two interstadials
(Domuratovian and Mrongovian) have been identified. However, substantial palynological evidence with complete pollen sequences and absolute datings exists for organic sediments of five interglacials: Augustovian, Ferdynandovian, Mazovian, Zbójnian and Eemian. Other interglacials (Malopolanian and Lubavian) are not sufficiently supported palynologically and especially the Lubavian Interglacial geological position and age are debatable.

of all the interstadial periods of the Quaternary stratigraphic scheme of Poland, Mrongovian and Domuratovian (Lower-Middle Pleistocene), Brörup/Amersfoort, and Rudunki/Odderade (Early Vistulian) are based on palynological determinations and ${ }^{14} \mathrm{C}$ and TL datings. An interstadial identified within the Middle Vistulian (Grudziądz) was established on the basis of sedimentological studies and TL datings of fluvial deposits of the Rzęczkowo Formation, the Lower Powiśle, and from the results of palynological analyses and ${ }^{14} \mathrm{C}$ and TL datings from the Konin region (Maliniec I, Maliniec II; Stankowski et al., 1995). 

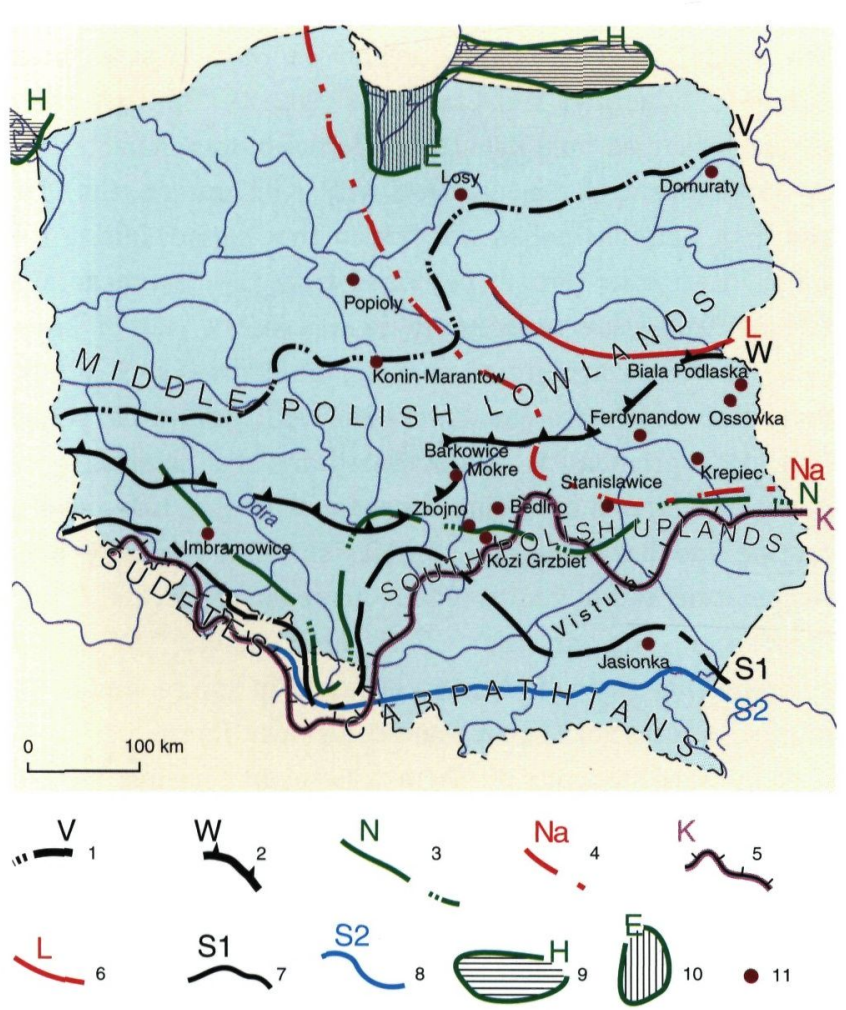

Fig. 2. Distribution of interglacial sites quoted in text with extents of the Scandinavian ice sheets in Poland (compiled after: Lindner, 1984; Lindner \& Marks, 1994; Marciniak \& Lindner, 2003; Marks, 2003). 1 - Vistulian Glaciation, 2 - Wartanian Glaciation, 3 - Nidanian Glaciation, 4 - Narevian Glaciation, 5 - Krznanian Glaciation, 6 - Liwiecian Glaciation, 7 - Sanian 1 Glaciation, 8 - Sanian 2 Glaciation, 9 - Holsteinian sea extent, 10 Eemian sea extent, 11 - Interglacial site.

\section{Interglacial stratotypes}

\section{Augustovian (Bavelian Complex or Cromerian I) Interglacial}

In the last ten years within the framework of detailed geological mapping in the Augustów Plain (NE Poland), glacial and interglacial sediments of the Lower Middle Pleistocene were determined. In boreholes at Szczebra, Kalejty, Zielone Królewskie, Janówka, Sucha Wieś, Czarnucha, Żarnowo and Komorniki (Fig. 3) interglacial lake deposits, the oldest in Poland, were documented by palynological and geological investigations (Ber, 1996, 2000; Janczyk-Kopikowa, 1996; Ber et al., 1998; Winter, 2001; Nitychoruk et al., 2000; Kacprzak et al., 2002). At present, the Augustów Plain area is a key region for the stratigraphy of the Lower Middle Pleistocene in Poland and neighbouring areas. Thanks to sedimentological, palaeoclimatic (palynology, macrofossils, malacology, diatoms, 0 and C isotopes), chemical, magnetic susceptibility and palaeomagnetic investigations, the sections with interglacial lacustrine deposits are now one of the most thoroughly examined deposits in Poland.
In the Szczebra stratotype profile (Fig. 4) the Augustovian Interglacial sediments, comprise silty-clayey rhythmites, lacustrine clay, silt and fine sand with occasional gyttja and peat layers, and represent a boreal floristic succession with Pinus-Betula-Larix and Azolla filiculoides during the first (I) temperate substage, and Pinus-Azolla-Picea (Azolla-Salvinia) with thermophilous taxons Carya, Juglans, Celtis, Eucommia, Salvania, Trapa during the second (II) temperate (climatic optimum) substage. Three cold substages are generally characterized by boreal and subarctic vegetation (Janczyk-Kopikowa, 1996; Ber et al., 1998). The entire lacustrine series, which is $16.7 \mathrm{~m}$ thick, includes a rich mollusc fauna throughout. In the Kalejty pollen diagram (Fig. 5; Winter, 2001) at the beginning of the older warm stage (Kal 2 - Kal 4) Pinus pollen are dominant with an admixture of Picea, Betula, Quercus and high frequencies of Cyperaceae. Gradually the boreal forest got

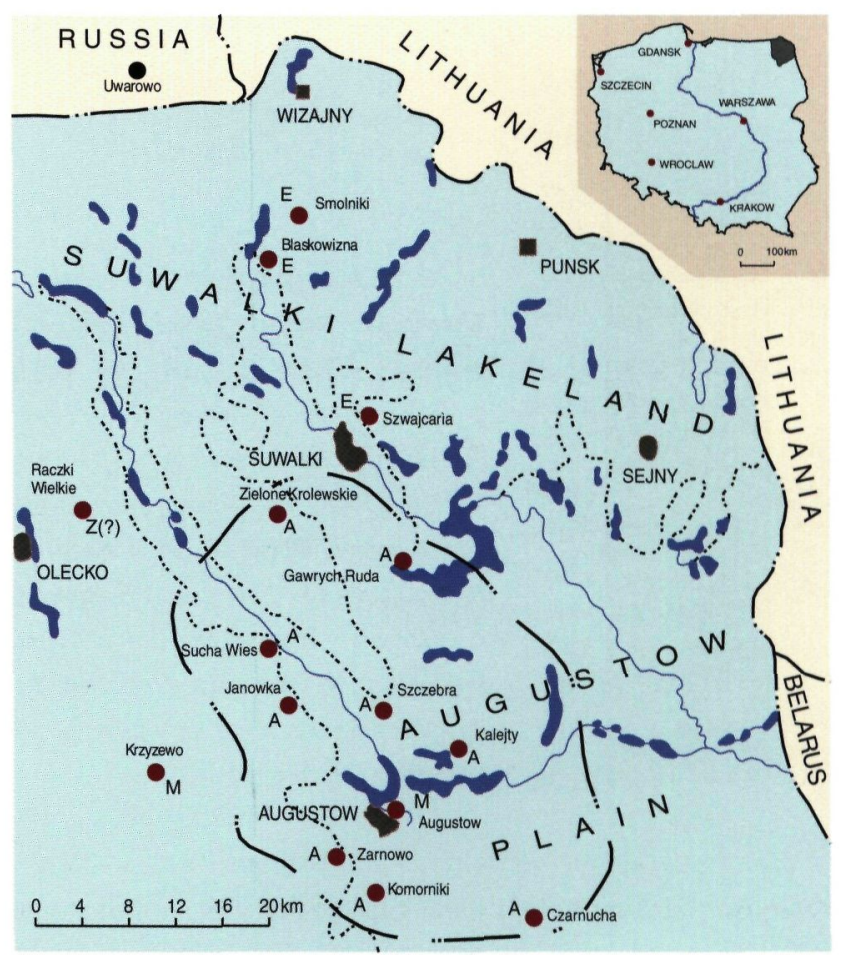

Fig. 3. Location of key interglacial sites in north-eastern Poland and probable extent of the Augustovian Interglacial buried lake. A - Augustovian Interglacial, M - Mazovian Interglacial, Z - Zbójnian (?) Interglacial, E - Eemian Interglacial.

enriched by Alnus, Ulmus, Tilia and Corylus. The assemblage indicates the presence of a mixed coniferous - deciduous forest. The occurrence of deciduous forest with high frequencies of Quercus, Carpinus as well as considerable share of Ulmus and Corylus is characteristic for the younger warm stage (Kal 6 Kal 8). The presence of Juglans, Carya, Ilex, Viscum, Hedera and Azolla indicates temperate climatic conditions. In the upper part of this sequence Tsuga pollen occurs. The cold stage separating two warm stages is marked by very high values of Betula and herb plants: Cyperaceae, Gramineae and 


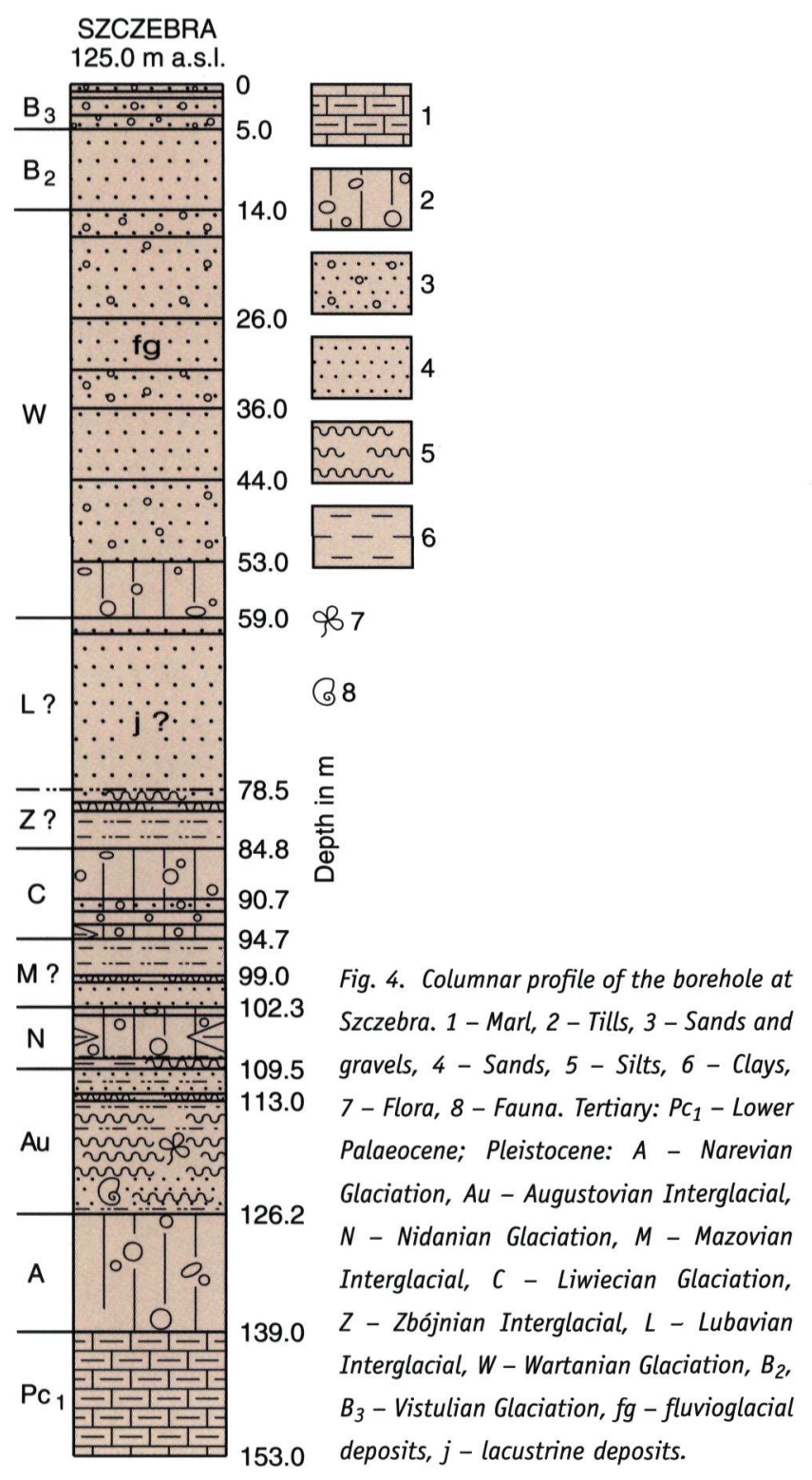

Artemisia, also by Betula nana type pollen. Two warm stages are interpreted by Winter (2001) as individual interglacials, but the rank of the cold one is controversial. The occurrence of Betula nana suggests the glacial stage. In the Czarnucha profile the lake and fluvial deposits represented by a lacustrineboggy-fluvial sequence are 32 metres thick. There are two temperate climatic periods recorded in the pollen diagram. The characteristic features of the first, older one are domination of pine forest with Picea and Betula, an admixture of Corylus, Quercus, Ulmus, Tilia, and the presence of massulae Azolla filiculoides. The climatic optimum of the pollen succession is characterized by development of deciduous forest with Quercus, Ulmus, Carpinus, Corylus and Acer, Fraxinus, Celtis, Ligustrum, Trapa, Salvinia as well as with Azolla filiculoides.

Summarizing, 2 warm climatic periods were identified in the Augustovian Interglacial on the basis of palynological investigations of interglacial sections from Kalejty, Zielone
Królewskie, Gawrychruda, Szczebra, Janówka, Sucha Wieś, Żarnowo, Komorniki and Czarnucha (Fig. 3). The first warm period, described from Kalejty and Żarnowo, was characterized by development of mixed forests with pine, spruce, elm, oak and lime. Carpinus pollen was rare in that period. During the warm interstadial period, described from the Czarnucha and Zielone Krolewskie sections, there was also a lack of hornbeam, whereas contribution of thermophilic trees such as oak, lime, elm and hazel was lower. The youngest warm period (climatic optimum) is characterized by the abundance of hornbeam. Pine is rarer, and the amount of elm, lime, maple, ashtree and hazel increase. Species showing relatively high temperature and humidity requirements appear: Celtis, Carya, Pterocarya, Juglans, Ilex, Vitis and Buxus. The forest environments gradually became enriched in spruce, and again in pine to form mixed hornbeam-spruce-oak forests.

Eight local horizons of macro-scale plant remains, marked as L MAZ 1-8, were distinguished in the Czarnucha section (Stachowicz-Rybka, 2003) where, like in the Sucha Wies section, multi-component laboratory investigations (mineralogical, chemical and isotopic), and palynological, malacological, diatom and palaeomagnetic studies were conducted. Results of these investigations are now in press. All of the studies, along with palynological analyses, characterize both the history of vegetation development in the interglacial reservoir and climatic changes.

Preliminary results of diatom studies enabled identification of 5 Local Diatom Assemblage Zones - L DAZ (Marciniak, 2003): DCz 1 Fragilaria-Stephanodiscus-Aulacoseira; DCz 2 Fragilaria-Stephanodiscus; $\mathrm{DCz} 3$ Stephanodiscus-FragilariaCyclotella; $\mathrm{DCz} 4$ (with $\mathrm{DCz} 4 \mathrm{a}$ and $\mathrm{DCz} 4 \mathrm{~b}$ ) StephanodiscusPeriphyton s.l.-Aulacoseira ambigua; DCz 5 Fragilaria-Periphyton s.l.-Aulacoseira. Quantitative and qualitative changes in diatom assemblages, in particular within the Stephanodiscus genus, indicate high similarity to the diatom assemblage typical of the Ferdynandovian Interglacial. The main difference, however, is the high contribution of euryhaline diatoms and the lack of Cyclotella diatoms (oligohalobic) in the Czarnucha section (Marciniak, 2003). In the Komorniki profile, which is correlated to the Czarnucha section, there is a benthic/periphytic, planctonic-benthic/periphytic, periphytic and generally oligotrophic, mesoeutrophic and eutrophic type diatom succession reflecting lake changes from a shallow lake to a lake of medium depth, and finally to a shallow and overgrown lake (Khursevich et al., 2004).

In the lake sediments at Szczebra some mollusc species (Bithynia leachi, Pisidium supinum) suggest moderate climatic conditions (Skompski \& Ber, 1999). Another molluscan species (Valvata naticina, Pisidium supinum, Sphaerium solidum) indicates that in this lake basin running water existed. The Komorniki malacofauna represents species of Viviparus sp., Valvata naticina Menke, Lithoglyphus jahni Urbański, Fagotia cf. wuesti Meijer, Sphaerium cf. rosmalense Meijer, Pisidium 

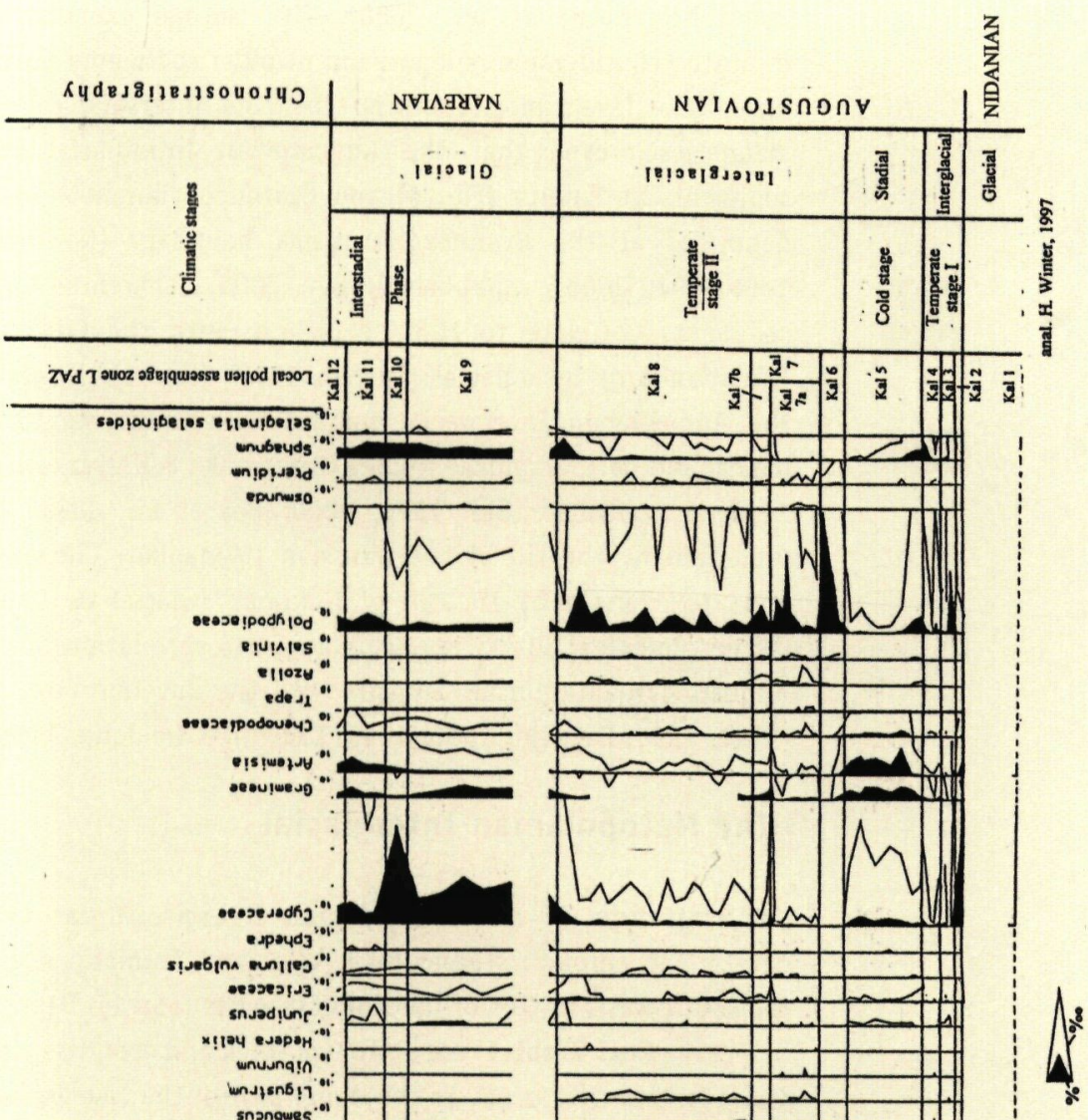

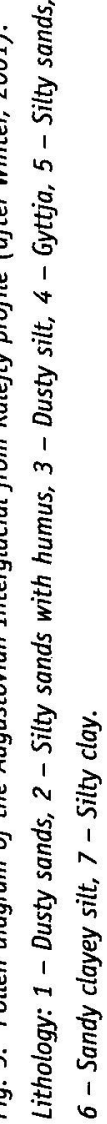




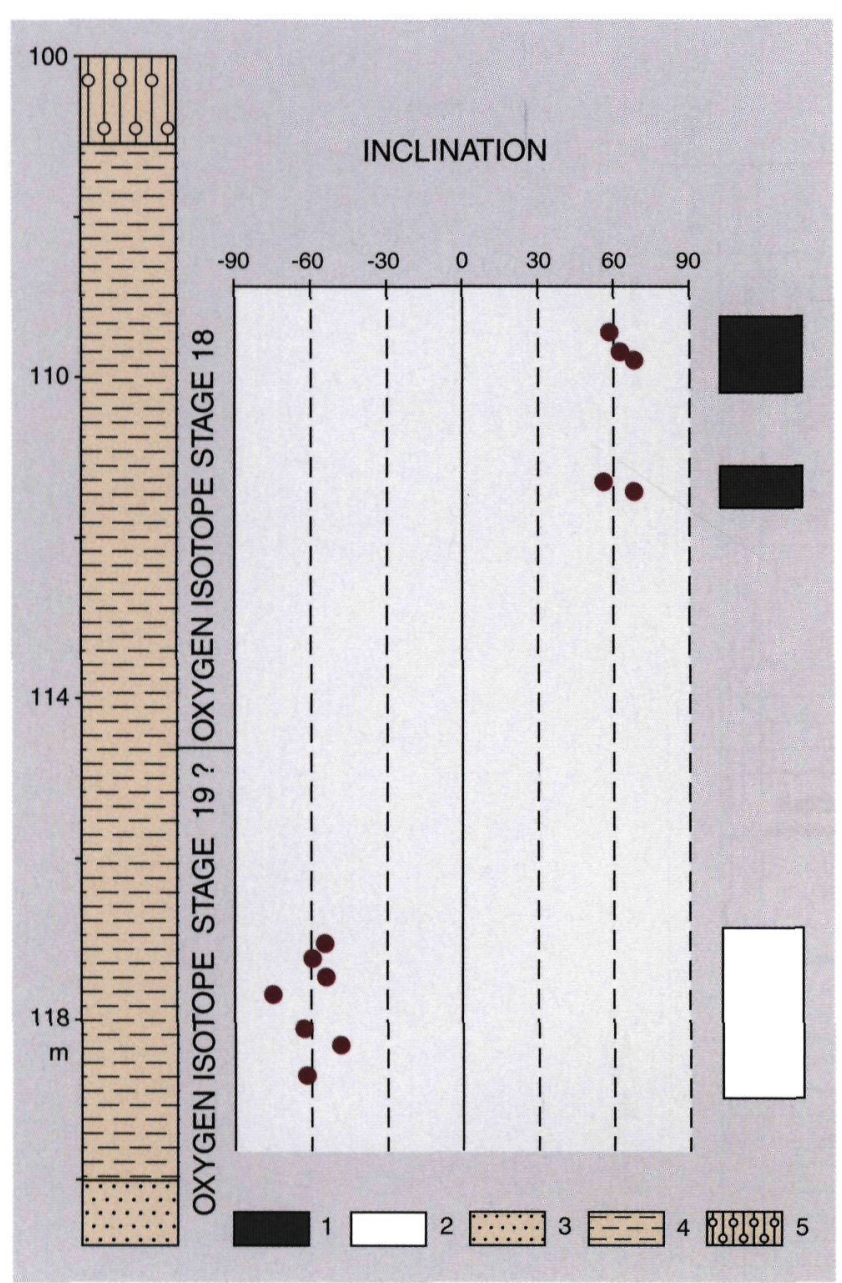

Fig. 6. Palaeomagnetic dating of sediments of the Augustovian Interglacial in the Kalejty section (after Nawrocki, 1996, unpublished). 1 - Normal polarity, 2 - Reversed polarity, 3 - Sands, 4 - Silts and clays, 5 - Tills.

sulcatum (Wood) and Pisidium amnicum (Müller) (Khursevich et al., 2004). This suggests the existence of a drained lake or flood-plain reservoir that the molluscs inhabited. The presence of stagnophilous species indicates the mobility of the water environment. Among the extinct species of molluscs Fagotia cf. wuesti Meijer and Neumayria (Parafossarulus) crassitesta (Brömme) are found in the Pleistocene sediments of Poland for the first time. These species are characteristic of the Bavelian Complex of the Netherlands. Additionally, the presence of pontian molluscs in the Komorniki malacofauna confirmed an affiliation of the described reservoir to the Black Sea basin. However, in the interglacial lake sediments in the Komorniki borehole for the first time in Poland shells of the Fagotia cf. acicularis (FERRUSAC) and rests of the small vertebrates Microtus (Pallasiinus) protoeconomus REKOVETS and M. (Pallasiinus) ex gr.economus PALL have been found (Khursevich et al., 2004).

Isotopic $\delta^{18} 0$ and $\delta^{13} C$ values were examined at Kalejty and Szczebra profiles from organic lake sediments of the Augustovian Interglacial (Jędrysek, 1997, unpublished; Ber,
2000; Nitychoruk et al., 2000). The isotope examination indicates considerable redeposition of older sediments during lower lake levels mostly during the cool intervals. Palaeomagnetics proved that the Augustovian Interglacial lake sediments at Kalejty (Fig. 6) and Czarnucha boreholes were deposited at the Brunhes/Matuyama boundary (Nawrocki, 1996,1997, 2003, unpublished; Ber, 2000). Therefore these sediments correlate to MIS $18 / 19$, i.e. with the Cromer I (Waardenburg) Interglacial (Turner, 1996) (Fig. 1). However, the Augustovian Interglacial sediments according to lithological and petrographical studies (Czerwonka \& Krzyszkowski, 1995, unpublished; Ber, 1996, 2000; Ber et al., 1998) are underlain by the till of the Narevian (Menapian) Glaciation and are overlain by the till of Nidanian (Glacial A, DorstCromer Complex) Glaciation. This suggests correlation of the Augustovian Interglacial deposits with the Bavelian Complex (West, 1996; Zagwijn, 1992, 1996; Zagwijn \& De Jong, 1984).

\section{The Malopolanian Interglacial}

The stratotype of the Malopolanian Interglacial has been determined through studies on a karst and faunistic site in the south-western part of the Holy Cross Mts (Fig. 2). Deposits in a cave (Kozi Grzbiet) are up to $9 \mathrm{~m}$ thick and comprise clays and poorly sorted sands. In the upper part of the cave palaeomagnetic studies on the clays have revealed the Brunhes/ Matuyama boundary (Fig. 7) (Glazek et al., 1977; Lindner et al., 2001). A rich faunistic assemblage of speleothems including numerous snail shells (i.e. Helicigona banatica, Soosia dodonta, Isognomostoma personatum etc.), amphibian and reptilian bones (Natrix cf. natrix, Triturus cf. cristatus) and mammalian remains (i.e. Lemmus lemmus, Castor fiber, Sus scrofa, Mimomys savini, Ursus deningeri), and mammal bones FCL/P dated at 700000 - 550000 BP, proves their Cromerian II (Westerhoven) age (Glazek et al., 1976; Lindner, 1982, 1984, Lindner et al., 2004).

Floristic characteristics of the Malopolanian Interglacial were probably recorded in organic sediments of the Jasionka section near Rzeszów only (Fig. 2). These sediments contain an incomplete interglacial pollen succession likely of interstadial character, from pine through mixed forests (with small areas covered by deciduous forests) to a very short - lasting subarctic environment and the following expansion of Pinus dominated forests (Dąbrowski, 1967; Lindner, 1984). According to Lindner et al. (2004) this interglacial is also documented by organic deposits at Lowisko (Stuchlik \& Wójcik, 2001). Recently, probable Malopolanian Interglacial organic lake sediments were indicated by palynological investigation of the Domuraty borehole, northeastern Poland (Kacprzak et al., 2002; Lisicki \& Winter, in press). The Domuraty pollen succession includes 2 warm periods with high contribution of deciduous trees. The older period is characterized by the dominance of mixed forests with oak, elm, lime, hazel, pine and spruce. During the 


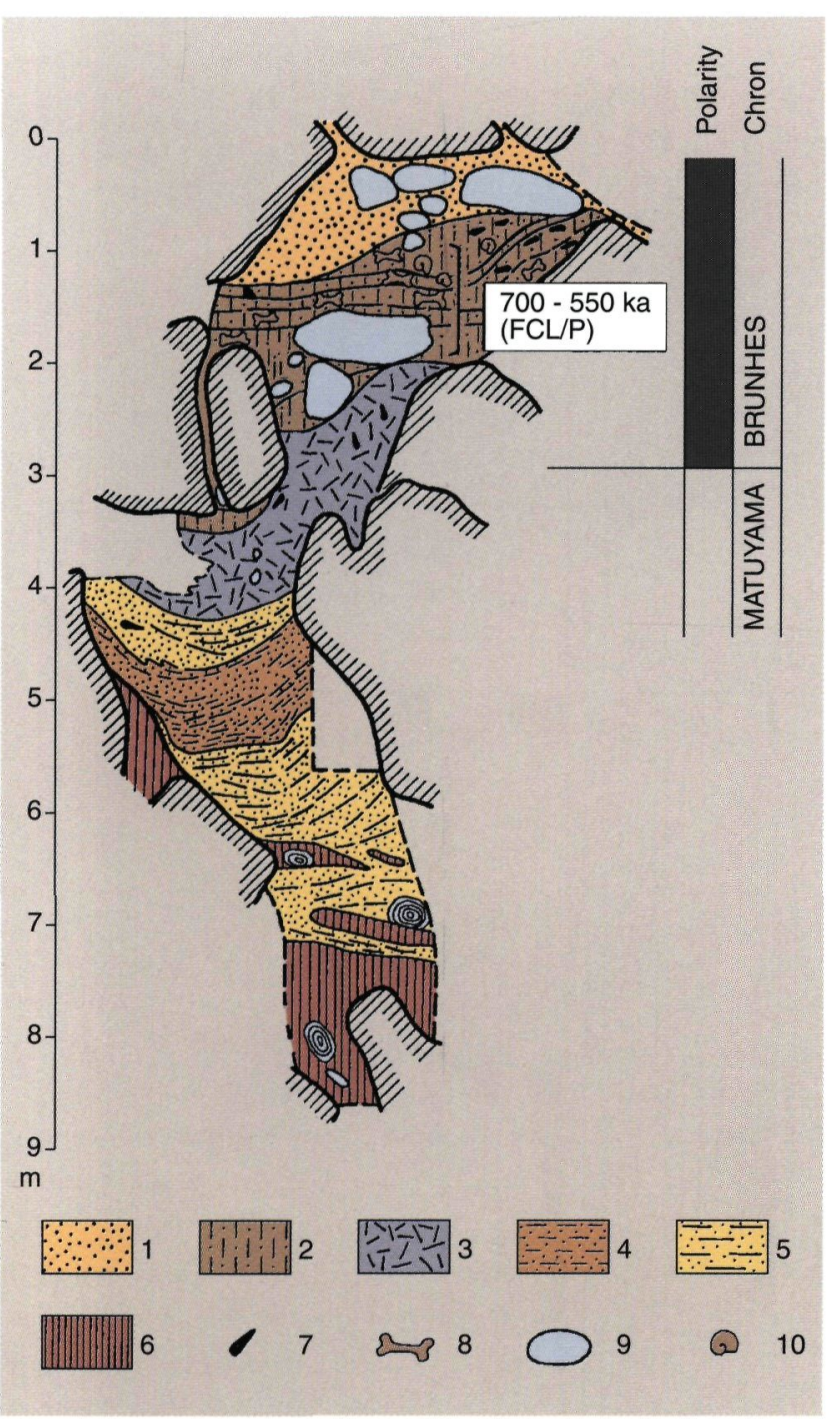

Fig. 7. Profile of cave deposits and palaeomagnetic data of the Malopolanian Interglacial from Kozi Grzbiet near Kielce (after Glazek et al., 1976; Lindner et al., 2004; with explanation modified). Sanian 1 and Sanian 2 Glaciations: 1 - Fine grained sands with Scandinavian material; Malopolanian Interglacial, 2 - Brown-yellow sandy clays, with bone fragments and snail shells; Nidanian Glaciation, 3 - 'Brecciated' clay; pre-Pleistocene, 4 - Cherry-red clayey sand, 5 -Poorly sorted sand with clayey lenses, 6 - Yellow-brown clay with carbonate concretions, 7 - Limestone debris, 8 - Bone remains, 9 - Larger limestone blocks, 10 - Snail shells.

younger warm period, hornbeam, maple and larch appeared in the forests. 0ak, fir and elm became more common. However, the geological setting of these deposits is unclear because of a lack of other types of investigations and datings.

\section{The Ferdynandovian (Voigtstedt) Interglacial}

Lacustrine organic sediments with complete interglacial pollen sequences of this age occur at Ferdynandów (Lublin Upland), the Belchatów excavation, and at Popioly and Stanislawice (Fig. 2). At the Ferdynandów site interglacial limnic sediments (limnic chalk, bituminous shale, gyttja and peat), about $15 \mathrm{~m}$ thick, represent a bi-optimal floristic succession with two warm periods characterized by moderate climate separated by a cool period with vegetation of the taiga type (JanczykKopikowa, 1975, 1991; Janczyk-Kopikowa et al., 1981) (Fig. 8). On the basis of pollen analysis six periods of vegetation development were indicated: I - Forest-tundra with dominance of Pinus and Betula; II - Coniferous forests with Pinus an admixture of Betula and Quercus; III - Mixed deciduous forests of the first climatic optimum with Quercus, Ulmus, Corylus, Abies, Tilia, Ilex and Taxus; IV - Coniferous forests with dominance of Pinus and Betula; V - Deciduous hornbeam forests (second climatic optimum) with Pinus, Betula, Ulmus, Quercus, Tilia, Alnus, Corylus, and Carpinus; VI - Coniferous forest of the taiga type with Pinus and Betula. Macroscopic plant remains preserved in interglacial sediments represent mainly local vegetation with Selaginella selaginoides, Salvinia natans, brasenia schreberi and Pilularia globielifa L. The interglacial sediments at Ferdynandow were also examined by detailed sedimentological and lithologic-petrographical studies (Rzechowski, 1996).

In the Belchatów excavation interglacial sediments were recognized in two profiles: Buczyna nad brukiem (JanczykKopikowa, 1991) and in the Czyżów Formation (Ea member) (Krzyszkowski, 1991) At Buczyna nad brukiem the interglacial sediments are represented by lacustrine and boggy deposits more than $3 \mathrm{~m}$ thick. In the lower part of this section pinebirch trees with Picea and Larix were indicated (JanczykKopikowa, 1991). In the climatic optimum there were high values of Ulmus, Quercus, Corylus with Tilia, Alnus, Abies, Carya, Buxus, Taxus, Ligustrum, Hedera and Celtis. Characteristic is the lack of Carpinus. The climatic optimum was moderate (Celtis and Carya) in character and the floral succession after the climatic optimum could not be observed.

In the Czyżów Formation (Ea member) the interglacial deposits consist of diatomites, lacustrine marl, silts and peats about $3 \mathrm{~m}$ thick. Pollen analysis from the lacustrine deposits indicated the following history of vegetation development (Kuszell, 1991): phase I - Tundra-forest with numerous herbaceous plants ad high content of Betula and Pinus; phase II coniferous forest dominated by Pinus and Betula with some admixture of Alnus, Quercus and Ulmus; phase III - deciduous forest with Quercus, Ulmus, Corylus and some admixtures of Picea and Abies; phase IV - coniferous forest with Abies, Picea and Alnus with some admixtures of Ulmus, Corylus, Tilia, Ilex and Viscum. Numerous macroscopic plant and wood remains, diatoms, molluscs, insects, freshwater fishes and other vertebrates were found here (Krzyszkowski, 1991). The most characteristic planktonic diatoms are: Cyclotella comta var., C. variosa, Stephanodiscus rotula and Aulacoseira granulata, Synedra spp., Fragilaria crotonensis Kitto, Asterionella formosa Hassal. The succession of diatoms indicates gradual eutrophication in the interglacial lake (Marciniak, 1991). However into the Czyżów 


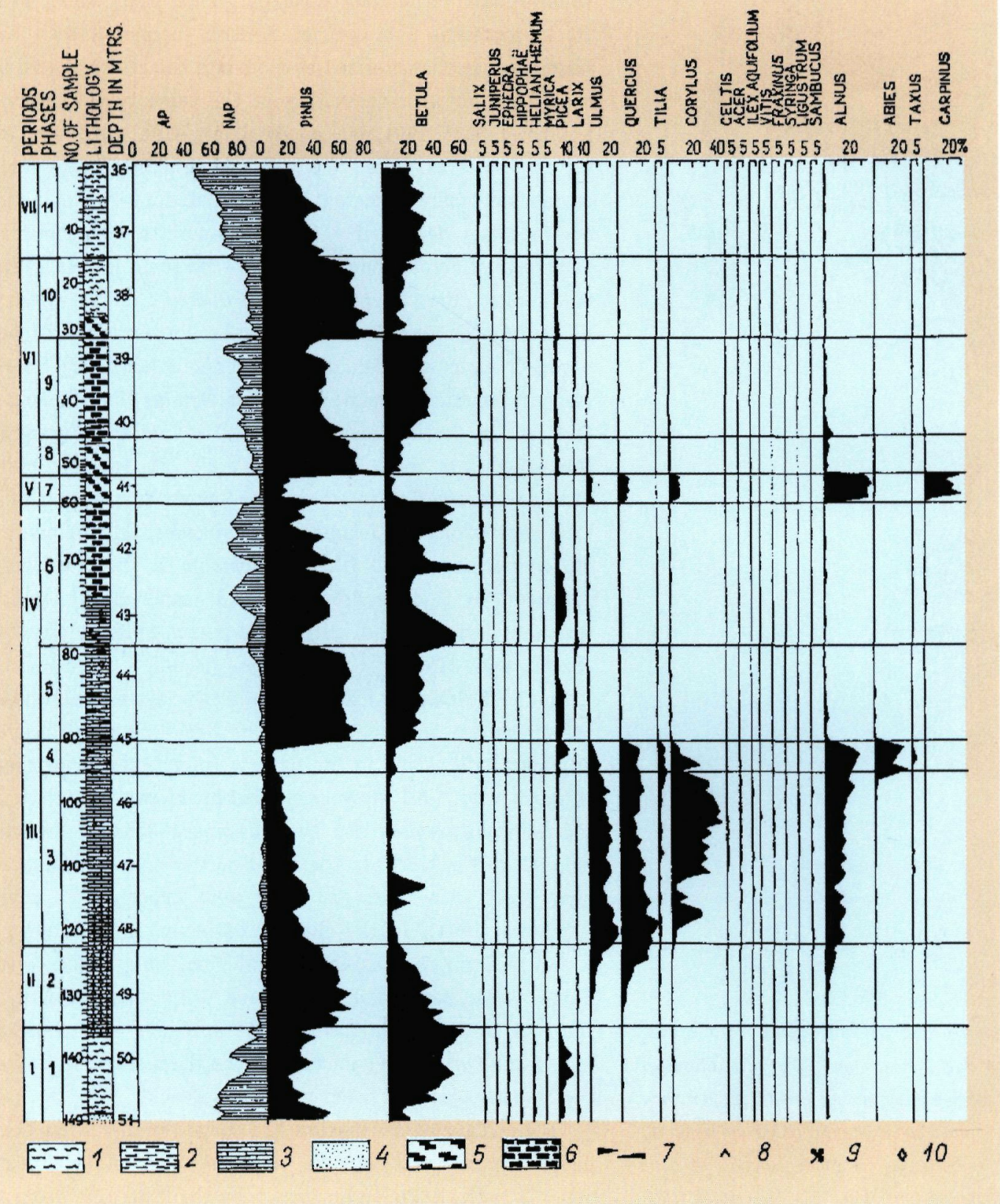

Fig. 8. Pollen diagram of the Ferdynandovian Interglacial from Ferdynandów borehole (after JanczykKopikowa, 1975). 1 -Silt, 2 - Clay, 3 - Lacustrine chalk, 4 - Sand, 5 - Peat, 6 - Gyttja, 7 - Bituminous shales, 8 - Diatoms, 9 Flora, 10 - Vivianite.

Formation a very poor molluscs fauna including 11 taxa only were indicated (Alexandrowicz, 1991). The main component is Valvata piscinalis, Bithynia tentaculata, Gyraulus allas and Pisidium moitessierianum as well as Succinea.

In the Popioly borehole the interglacial deposits are represented by silt and gyttja of $7 \mathrm{~m}$ thick. In the pollen diagram five phases of floral development were indicated (Winter, 1992): phase I - A period of pine forests with admixture of larches, spruces, birches and alders; phase II - A period of mixed deciduous forests ot the climatic optimum with predominance of oak, elms, hazels and pines; phase III - A period of deciduous forests with firs and yews; phase IV - A period of pine-alder forests with amixture of spruces and larches; phase V - A period of pine forests with birches and areas of intraforest meadows. Based on diatom succession five local diatom zones have been indicated in Popioly profile (Marciniak \& Lindner, 2003): PD1 - Periphyton-Fragilaria; PD2 - StephanodiscusCyclotella; PD3 - Periphyton-Stephanodiscus; PD4 Stephanodiscus-Aulacoseira; PD5 - Fragilaria-PeriphytonStephanodiscus-Aulacoseira.

In the Stanislawice borehole near Kozienice, Central Poland (Fig. 2), a series of lake and marsh deposits $3.73 \mathrm{~m}$ thick (Fig. 9) of the Ferdynandovian Interglacial were documented palynologically (Janczyk-Kopikowa \& Żarski, 1995). Four pollen periods have been distinguished in the pollen succession: the F1 period is characterized by of boreal pinebirch forests; the F2 period is indicated by thermophilous deciduous forests as the climatic optimum with Quercus, Ulmus, Corylus, Tilia, Acer and Fraxinus; in the F3 period there are mixed forests of the temperate climate with Picea, Abies, 


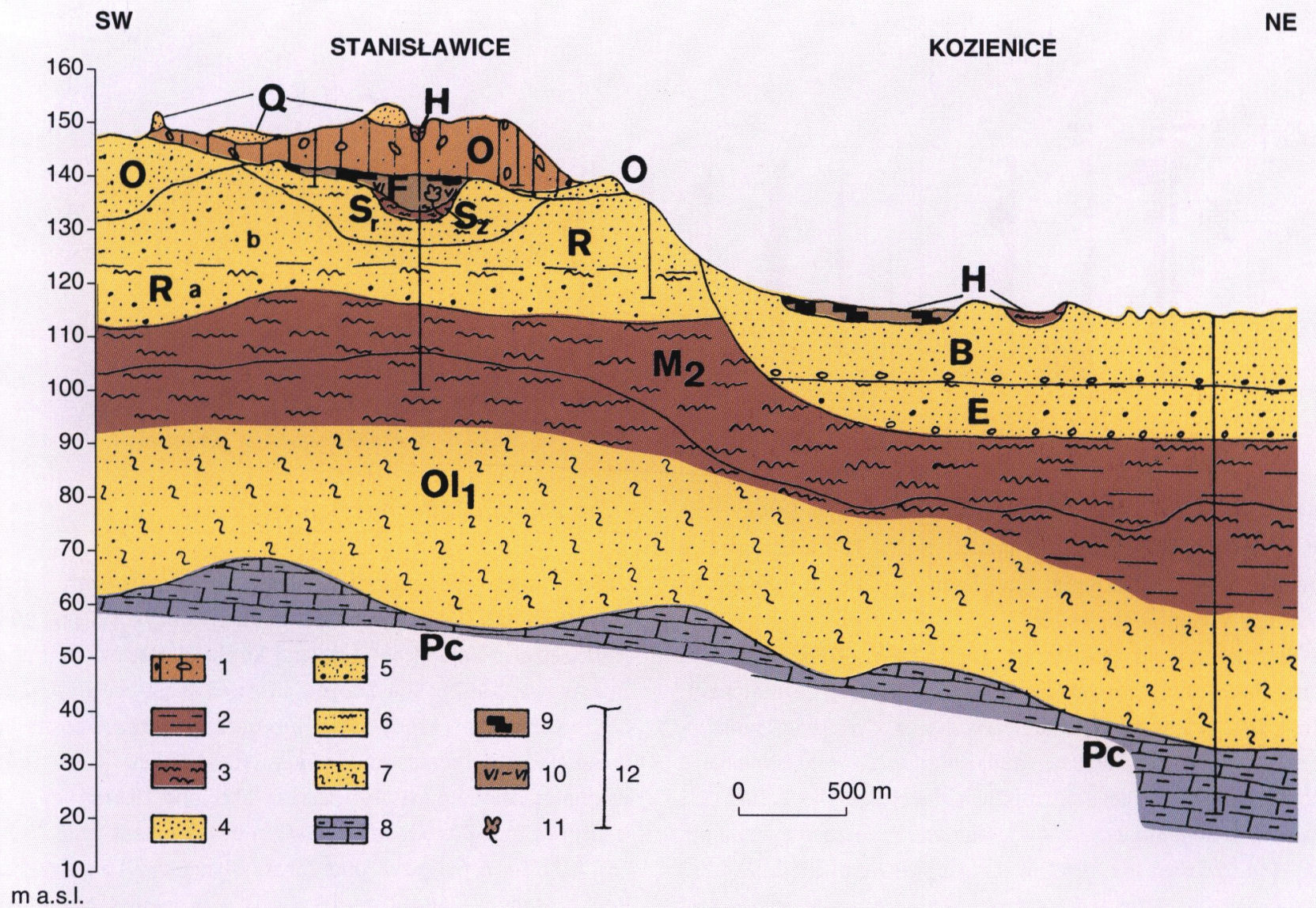

Fig. 9. Cross section of the Stanislawice section (after Janczyk-Kopikowa \& Żarski, 1998). 1 - Tills, 2 - Clays, 3 - Silts, 4 - Sands, 5 - Sands and gravels, 6 - Dusty sands, 7 - Glauconitic sands, 8 - Marls, 9 - Peats, 10 - Gyttja, 11 - Fossil flora, 12 - Borings. Pc - Lower Palaeocene, Ol 1 - Lower Oligocene, $M_{2}$ - Middle Miocene, Ra - Preglacial (cycle a), Rb - Preglacial (cycle b), $S_{r}$ - San 2 Glaciation, river facies, $S_{Z}-$ San 2, stagnant water facies, F - Ferdynandów Interglacial, 0 - Odra Glaciation, Ee - Eemian Interglacial, B - Vistulian Glaciation, H - Holocene, Q - undivided Quaternary.

Quercus, Ulmus, Tilia and Corylus; the F4 period is characterized by the domination of pine forest with spruce and birch and the lack of Carpinus. The absolute age of the lower part of interglacial series was evidenced by the TL method at 537000 $\pm 80000 \mathrm{BP}$, the middle part at $519000 \pm 78000 \mathrm{BP}$ and the upper one at $508000 \pm 76000 \mathrm{BP}$ (Fig. 9).

\section{The Mazovian (Holsteinian) Interglacial}

Organic lake and fluvial sediments of this interglacial are widespread in Poland and have been described from numerous (about 30) sites, among others at Barkowice Mokre (Sobolewska, 1952), Krępiec (Janczyk-Kopikowa, 1981; Lindner \& Marciniak, 1998) and 0ssówka in the vicinity of Biala Podlaska (Krupiński, 1988, 1995, 2000). The Mazovian (Holsteinian) Interglacial is the first period with a marine transgression limited to the northern part of NE Poland and to the lower Vistula valley (Fig. 2).

In the Barkowice Mokre (Central Poland) two profiles of interglacial lake sediments (black bituminous shales, silt, gyttja and dy) to $4.3 \mathrm{~m}$ thick were investigated by pollen analysis and macroscopical plant remains (Sobolewska, 1952). There are 3 main and 2 secondary forest periods: I - Birch-pine period of cold climate; II - Spruce-pine-alder subperiod with milder climate; III - Fir-hornbeam period of climate optimum; IV - Pine-birch period colder than during the climatic optimum; V - Birch-pine period with cold and dry climate (Fig. 10).

The lake deposits at Krępiec (the Lublin Upland) are almost $20 \mathrm{~m}$ thick and consist of sands, silts, peats and gyttja that were described as the Mazovian Interglacial on the basis of palynological (Janczyk-Kopikowa, 1981, 1991) and diatom investigations (Marciniak, 1988). Palynological analysis has shown a complete interglacial pollen sequence developed during four vegetation periods with the climatic optimum marked by Vitis and predominance of Carpinus and Abies (JanczykKopikowa, 1981, 1991) (Fig. 11). Period I was characterized by the predominance of Betula and Pinus. In period II Picea and Alnus predominated. Period III, representing the climatic optimum, has been devided into two subperiods with Taxus and Picea and Alnus (the first subperiod) and Carpinus, Abies, Quercus, Ulmus, Tilia, Corylus as well as Vitis silvestris and Azolla filiculoides into the second subperiod. Period IV is 


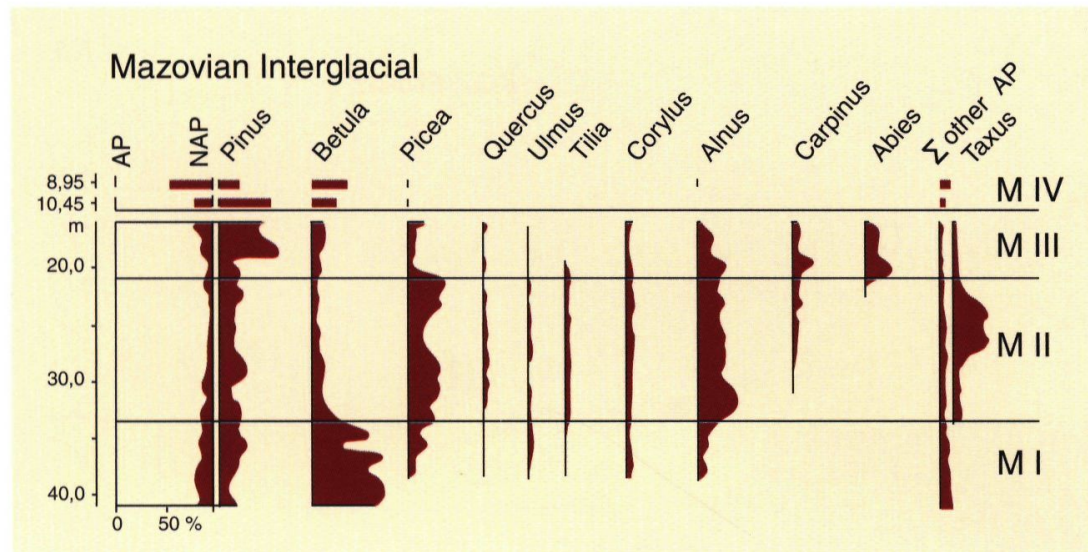

Fig. 10. Synthetic pollen diagram of the Mazovian Interglacial from Barkowice Mokre (after JanczykKopikowa, 1991). Percentage pollen scale is located at the base of left column.

characterized by the predominance of Pinus and Betula with an abundance of herbaceous plants (NAP). The lower part of the lake deposits at Krępiec have been TL-dated at 400000 BP (Lindner \& Marciniak, 1998).

Diatom analysis (Marciniak, 1980, 1983, 1988; Lindner \& Marciniak, 1998) shows four stages of diatom development. The L DAZ K-1 stage with Stephanodiscus, Cyclotella, Synedra, Fragilaria crotonensis Kitto and Asterionella fomosa gave a record of a deep meso-eutrophic palaeolake; the L DAZ K-2 stage with Stephanodiscus, Cyclotella and Aulacoseira granulata var. Angustissima is typical of a eutrophic lake; the L DAZ K-3 stage with Cyclotella and Stephanodiscus signals an increase of periphyton; the L DAZ K-4 stage is divided into two substages with dominance of periphitic diatoms and increasing abundance of Fragilaria suggesting overgrowth and shoaling of the palaeolake.

In the Ossówka located in the vicinity of Biala Podlaska (Krupiński, 2000), interglacial sediments are represented by lacustrine calcareous deposits of unusual thickness of $34.57 \mathrm{~m}$. They reveal the whole record of floristic changes in the Mazovian Interglacial, contained in borehole $9 \mathrm{~L}$ PAZ (Fig. 11): OS-A - Betula-NAP; OS-B - Betula-Pinus-(Picea-Alnus); OS-C Picea-Alnus-(Pinus); 0S-D - Picea-Alnus-(Taxus); 0S-E - TaxusPicea-Alnus with 3 substages; OS-G - Abies-Carpinus-Quercus(Corylus) with 6 substages; OS-H - Carpinus-Quercus-Abies with 7 substages and OS-I - Pinus with 2 substages. Borehole $15 \mathrm{~L}$ PAZ is also reflecting some episodes of vegetation development in the post-interglacial period (4 non-forest, shrub and tundra episodes separated by 3 episodes representing borealforest, interstadial or interphase climate). This section was also examined for the content of carbonates, $\mathrm{CaCO}_{3}$ and water. The lake sediments in the 0ssówka boreholes have been also interpreted in terms of stable oxygen and carbon isotopes (Nitychoruk, 2000). The isotopic curves correlated with results of pollen analysis (Krupiński, 2000) indicate relatively cool climatic conditions of the climatic optimum (Fig. 12). The malacofauna investigations show an abundance of Viviparus diluvians (KUNTH) and Lithoglyphus pyramidatus MILDF (Krupiński \& Skompski, 1995).

\section{The Zbójnian (Dömnitz) Interglacial}

Organic lake sediments of this age are known from, among others, Zbójno (Central Poland) (Lindner \& Brykczyńska, 1980; Marks et al., 1995) (Fig. 13), and Konin-Marantów (BorówkoDlużakowa, 1967). The Zbójno site was described by Lindner \& Brykczyńska (1980). The interglacial lake deposits are developed as peats and peaty silts about $8 \mathrm{~m}$ thick. Palynological analysis of these lake and marsh deposits indicated four periods of vegetation development from $\mathrm{Zb} I$ to $\mathrm{Zb}$ IV: $\mathrm{Zb}$ I - A period of pine forest with a small admixture of Betula, Quercus and Corylus; Zb II - A period of climatic optimum with rapid development of Tilia (Zb IIa) and then with decrease of Tilia and an increase of Alnus, Carpinus, Picea, Corylus and Quercus (Zb IIb); Zb III - A period with domination of coniferous trees; Zb IV - Period of pine increase (Fig. 13). Glaciolacustrine silts underlying the interglacial organic deposits in the Zbójno section were TL-dated at $388000 \mathrm{BP}$ and overlying at $236000 \mathrm{BP}$ (Lindner \& Brykczyńska, 1980).

In the Konin-Marantów excavation the organogenic lake deposits (three peat beds alternating with sands and detrital gyttja) of this age are about $9 \mathrm{~m}$ thick. On the basis of results of pollen analysis the whole vegetation development can be divided into three floral phases: I - A phase of clear birch-pine forests with willow and larch; II - A phase of dense forests, at first of alder-lime-hornbeam forests with oak, elm and hazel (IIa) and then of spruce-pine forests with fir, alder and birch (IIb); III - A phase of pine-spruce-alder forests (BorówkoDlużakowa, 1967).

\section{The Lubavian Interglacial}

Organogenic lake sediments of this age were recognized at the Losy site (Fig. 2), which has, according to Lindner \& Marks (1994), sufficient palynological and diatom documentation as well as thermoluminescence datings of glaciofluvial sands underlying lake marls at $273000 \mathrm{BP}$ and overlying the lake marls at $230000 \mathrm{BP}$ to locate them within the position of the Lubavian Interglacial. The interglacial sediments are developed 


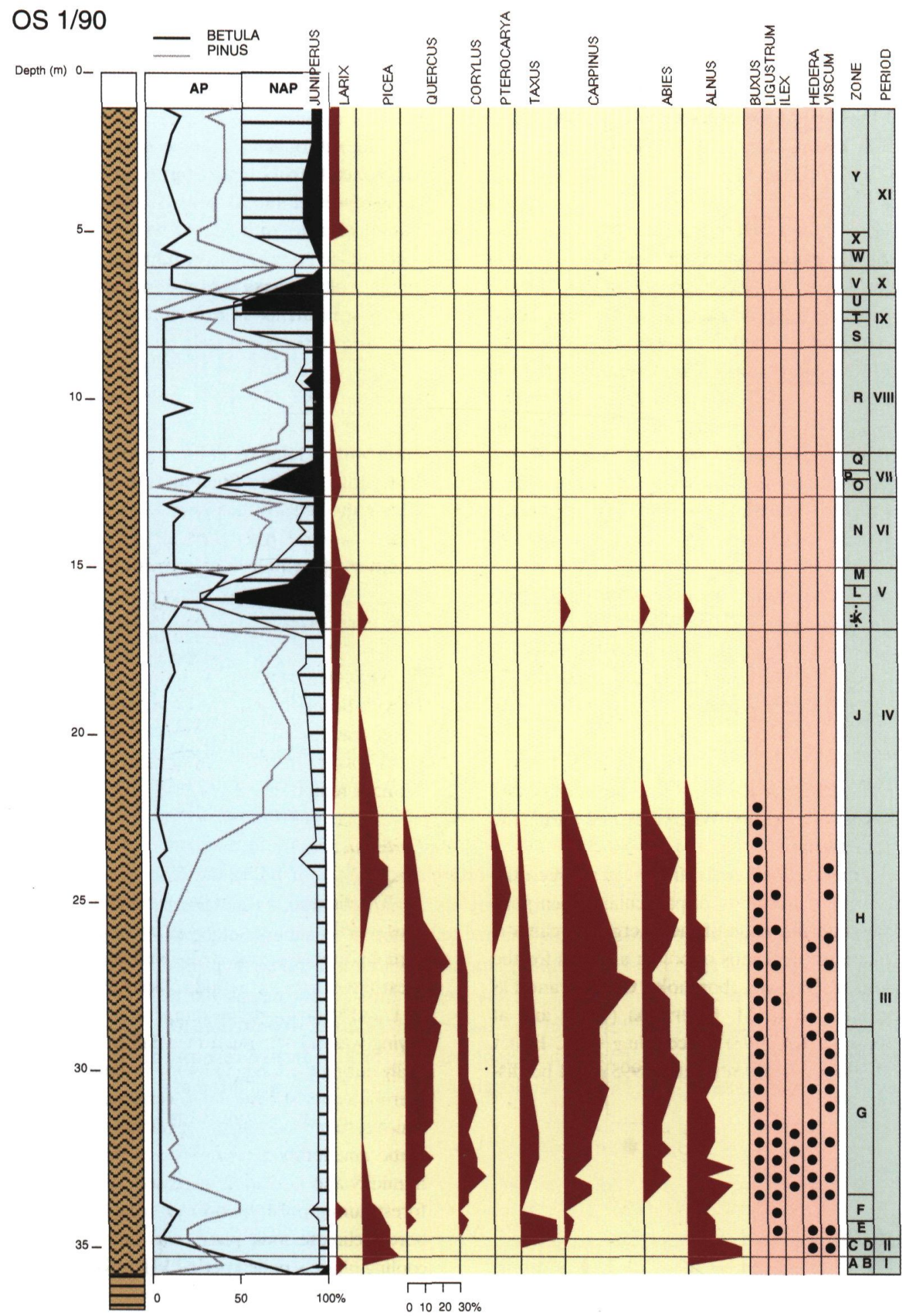

Fig. 11. Pollen diagram of the Mazovian Interglacial deposits at Ossówka near Bielsk Podlaski (after Krupinski, 1995, simplified by Nitychoruk, 2000).

as two beds of lake marl, an older bed of about 2 to $5 \mathrm{~m}$ thick and a younger bed of up to $10 \mathrm{~m}$ (Fig. 14). Palynological analyses documented four periods (Lu I - Lu IV) of vegetation development: I - A period of forests with domination of Pinus and Larix; II - A period where Pinus and Larix were accompanied by Picea, Quercus, Ulmus, and Typha latifolia; III - A period of forests with oak-birch domination and rarely Tilia; IV - A period with domination of Quercus with Corylus, Ulmus, Alnus and Tilia (Fig. 15). The age of this pollen succession is under discussion because development of the interglacial vegetation is very similar to the Eemian Interglacial succession. The interglacial sediments at Losy were also examined by diatom analysis (Tuszyńska-Gruza, 1984, unpublished). Sediments of this age are probably known also in the Belchatów section (Fig. 2) where are lacustrine and fluvial series of the so-called Chojny section are TL-dated at 264000 BP (Krzyszkowski, 1992). 


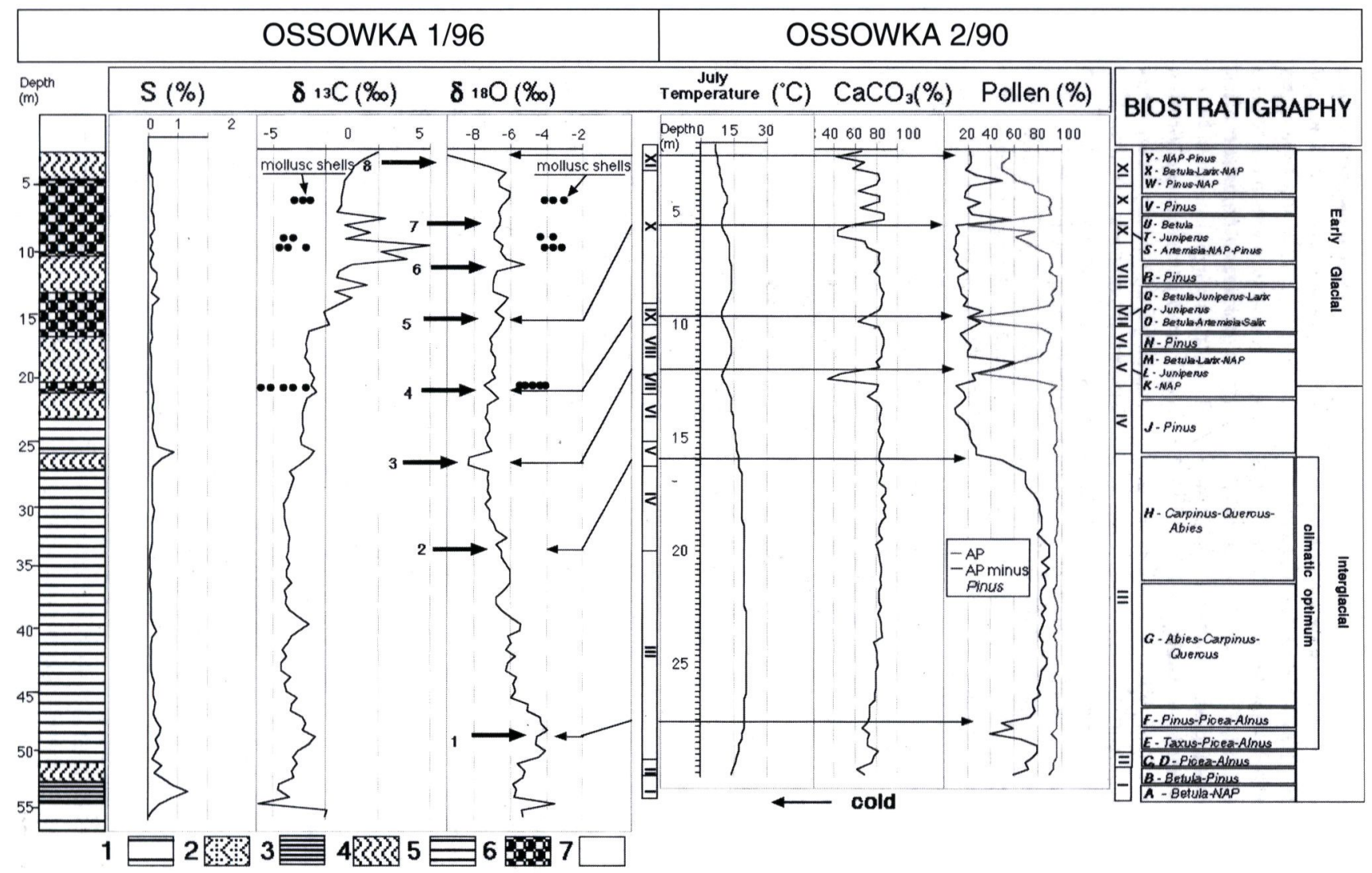

Fig. 12. Biostratigraphical correlation of the cores of boreholes at Ossówka (based on Krupiński, 1995; Nitychoruk et al., 1999, correlated by Nitychoruk, 2000). 1 - Late glacial clays and silts, 2 - Sands and sandy muds with organic admixture, 3 - Very thin laminated calcareous lake deposits, 4 - Homogeneous calcareous lake deposits, 5 - Laminated calcareous lake deposits, 6 - Concentrations of molluscs shells, 7 - Covering deposits.

\section{The Eemian Interglacial}

In Poland this interglacial is best known from paleobotanical studies. This is the second period with a marine transgression known in northern Poland. The marine sediments occur in the lower Vistula valley area only. They are composed of two clayey-silty series representing two separate marine incursions so called Sztum and Tychnowy (Makowska, 1986, 1991). The
Eemian Interglacial is known in Poland from over 300 sites with complete interglacial pollen successions, among others at Bedlno and Imbramowice (Środoń \& Goląbowa, 1956; Mamakowa, 1989; Lindner \& Marciniak, 1998) (Fig. 2).

At the Bedlno site, palynological and macrofloral analysis of the lake-marsh deposits, represented by gyttja, clay and peat series of $5 \mathrm{~m}$ thick, indicated four periods of vegetation development (Fig. 16). The EI period represents predominance

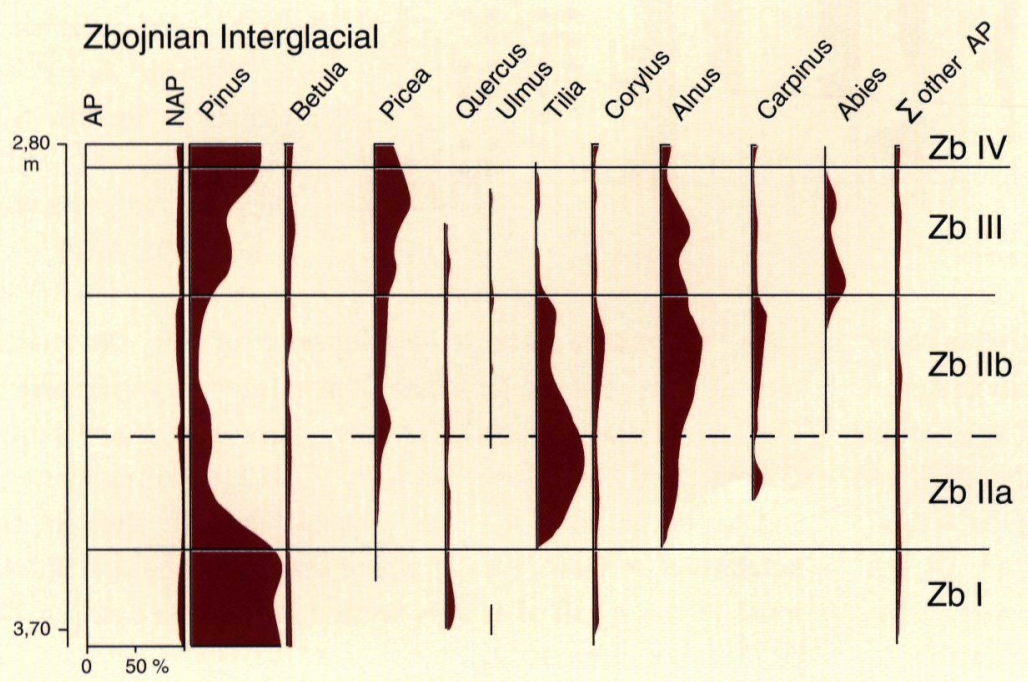

Fig. 13. Synthetic pollen diagram of the Zbójnian Interglacial from Zbójno (after Brykczyniska \& Lindner, 1980). Percentage pollen scale bar is located at the base of left column. 


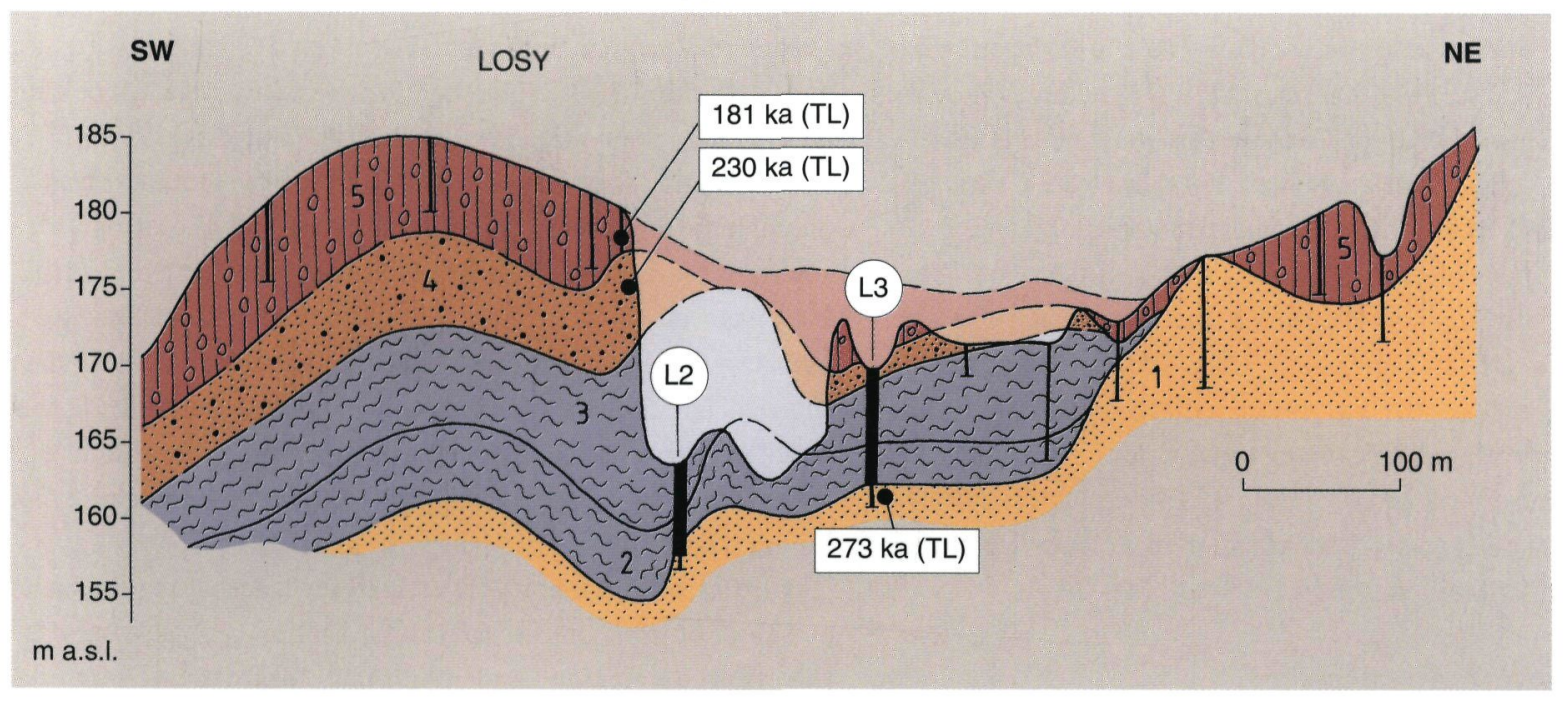

Fig. 14. Geologic section of interglacial lake sediments at Losy near Lubawa (after Krupinski \& Marks, 1986, modified by Lindner \& Marciniak, 1998). Odranian Glaciation: 1 - Sand; Lubavian Interglacial: 2 - Grey lake marl, 3 - Yellow-orange lake marl; Wartanian Glaciation, 4 - Sand with gravel, 5 - Till.

Fig. 15. Synthetic pollen diagram of the Lubavian Interglacial deposits at Losy (after Krupinski \& Marks, 1986, modified by Janczyk-Kopikowa, 1991). Percentage pollen scale bar is located at the base of left column.
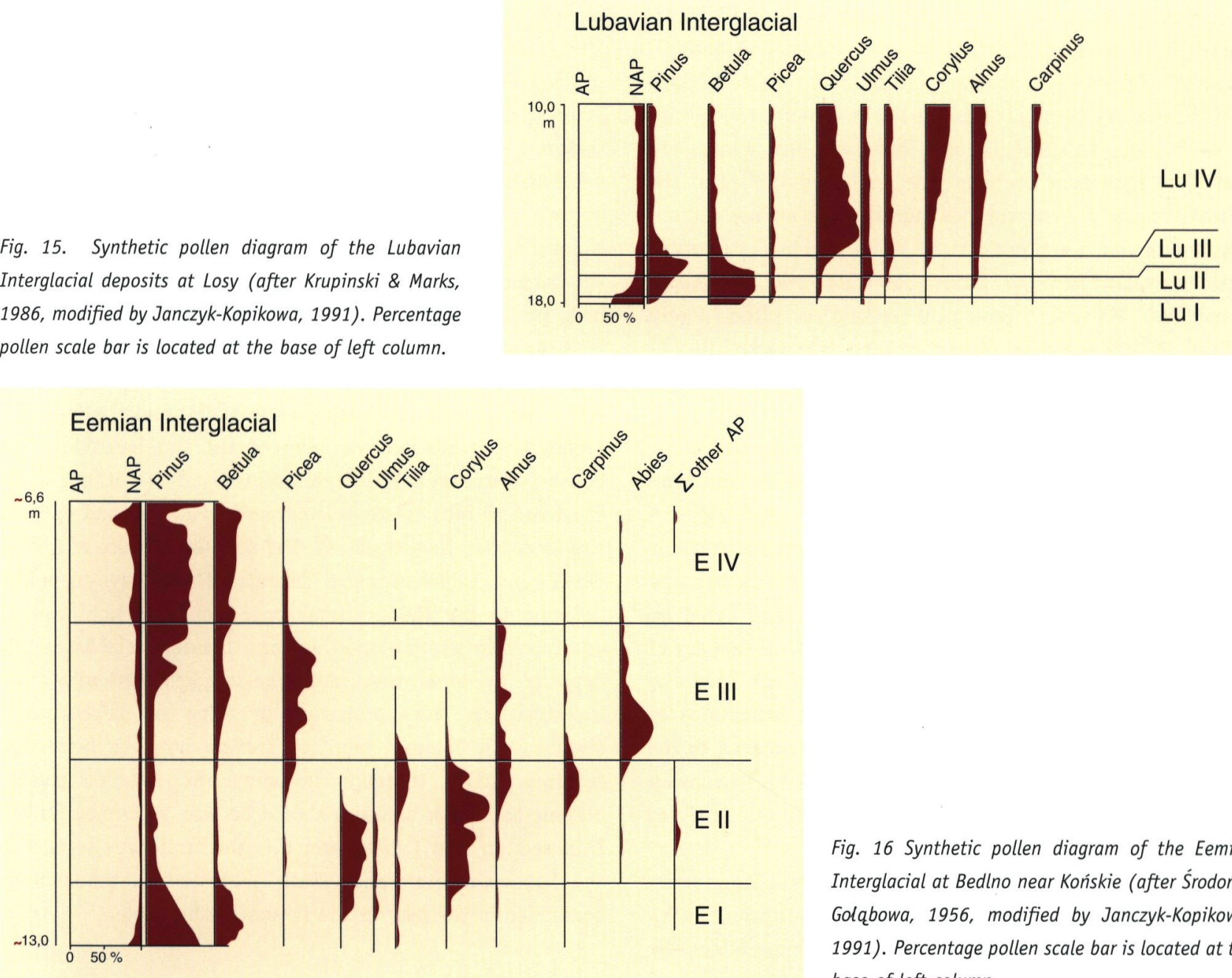

Fig. 16 Synthetic pollen diagram of the Eemian Interglacial at Bedlno near Koniskie (after Środoń \& Golabowa, 1956, modified by Janczyk-Kopikowa, 1991). Percentage pollen scale bar is located at the base of left column.

of forests with pine-birch with an admixture of Quercus, Ulmus, Tilia, Carpinus, Corylus and Alnus. In the climatic optimum (E II period) deciduous forests with predominance of Quercus, Corylus, Tilia and traces of Picea have been deter- mined. In the EIII period Picea and Abies were indicated with an admixture of Alnus, Pinus and Betula. The last one (the EIV period) was represented by pine-birch forests with Picea and Larix (Środoń \& Goląbowa, 1956). 
Pollen and diatom analyses were done at the Imbramowice section (Mamakowa, 1989; Kaczmarska, 1976) where lake sediments (silts and gyttja) of Eemian age were distinguished. Palynological analyses (Mamakowa, 1989) indicated similarly as in the Bedlno four periods of vegetation development: E 1 Forests with Pinus-Betula; E 2 - Forests with Pinus-Betula-Ulmus; E 3 - A period of Quercus-Fraxinus-Ulmus forests and the last one (E4) the climatic optimum with Corylus-Quercus-Tilia. Diatom studies (Kaczmarska, 1976) indicated mainly littoral taxons (mostly Fragilaria) characteristic for a shallow lake existing during the climatic optimum. TL datings of the preand post-Eemian deposits indicate that in Poland this interglacial period is dated at about $125-130000 \mathrm{BP}$.

\section{Synthesis and discussion}

The Pleistocene stratigraphic scheme of Poland includes 7 interglacial periods: Augustovian (Bavelian Complex or Cromerian I), Malopolanian (Cromer Complex II or III Interglacial), Ferdynandovian (Voigtstedt), Mazovian (Holsteinian), Zbójnian (Dömnitz), Lubavian (Schöningen) and Eemian. Identification of these periods should be based on results of detailed and multidisciplinary investigations which are applied to stratotype sections. The published studies of the sections assumed as stratotypes indicate that mainly palynological analyses were performed. The individual stratotype sections usually have no datings for their lower and upper boundaries. Moreover, geological setting is often poorly defined. All of these facts cause that there is the possibility of assigning several ages to the deposits, indicating the need for an alternative: e.g. Bavelian or Cromerian I.

The most thoroughly examined interglacial stratotype sections of Poland are those for the Augustovian, Mazovian and Eemian. In constrast, the Ferdynandovian and Zbójnian interglacial deposits were examined largely by palaeobotanic investigations with fragmentary palaeomagnetic studies and TL datings. Cave sediments at Kozi Grzbiet were dated by FCL/P and palaeomagnetic methods indicating that they are of Malopolanian Interglacial age. The datings do not have any equivalent in the results of palynological investigations or other studies from the Polish Lowlands. The same refers to the Losy site, assumed a stratotype locality for the Lubavian Interglacial, with problematic results of palynological analyses and unclear geological setting.

For the Augustovian Interglacial examinations were performed at the stratotype sections of Czarnucha, Sucha Wieś, Szczebra, Komorniki and partly at Kalejty. All of the localities occur within the Augustów stratotype area and within the same lake basin. Multidisciplinary investigations, including sedimentological, palaeoclimatic, chemical, mineralogical, palaeomagnetic and magnetic susceptibility studies, are now in progress in the extremely important section of Żarnowo and in Domuraty and Janówka. The most thoroughly examined Mazovian Interglacial sections are those at Krępiec and Ossówka. The Krępiec section was investigated palaeobotanically, including diatom studies (Marciniak, 1988). TL datings were also made. For the 0ssówka section, besides palynological analyses (Krupiński, 2000) and TL datings, also stable oxygen and carbon isotope investigations (Nitychoruk, 2000) as well as malacofaunal studies (Krupiński \& Skompski, 1995) were performed. The stratotype sections of the Eemian Interglacial are supported largely by palaeobotanic, faunal and TL dating data. Magnetic susceptibility investigations have lately been conducted for 8 locations (Ciszek, 2004, unpublished).

Further supplementary investigations meeting requirements of the definition of the stratotype section are necessary for the Ferdynandovian and Zbójnian Interglacial sections. Besides palaeobotanic studies and TL datings, there are no other investigations of these sections. Reasonably comprehensive studies were performed for the Czyżów Formation representing the Ferdynandovian Interglacial (Krzyszkowski, 1991), although no isotopic, magnetic susceptibility and palaeomagnetic analyses have been made. The Zbójnian Interglacial has not been sufficiently documented. The Zbójno section and the Konin-Marantów sections were investigated palaeobotanically, and TL dated. The Raczki Wielkie borehole section (Woźniak, 1989), frequently cited in the Polish literature, has been assigned to the Zbójnian Interglacial on the basis of pollen analysis of 2 samples collected from 2 peat beds and one TL dating of fluvial deposits.

A separate, but important problem, concerns investigations of the Malopolanian and Lubavian interglacials. The Malopolanian (Cromer Complex - II or III) and the Lubavian (Schöningen) interglacials were named and located in the Polish Pleistocene stratigraphic scheme either without or on the basis of incomplete paleobotanic evidence, and without supplementary investigations. The Kozi Grzbiet site as well as FCL/P and palaeomagnetic datings of the cave deposits, pointing to the Malopolanian Interglacial, do not have an equivalent in any lowland locations of interglacial lacustrine deposits. Therefore, they cannot be supplemented with other investigations. Very promising in terms of palaeobotanic studies is the Domuraty borehole section, however the section requires further thorough investigations. Detailed palaeobotanic and other analyses should be also performed for the Losy section near Lubawa which is the stratotype section of the Lubavian Interglacial. Such analyses will probably be conducted in the near future in another borehole.

\section{Conclusions}

In the stratigraphical scheme of Poland, the following interglacials are well-established, whereas others remain problematic: Well-established:

- Three interglacials: Augustovian, Mazovian and Eemian are 
established on the basis of complete palynological profiles and documented by other kinds of investigations as well as by TL-dating.

Problematic:

- Two interglacials: Ferdynandovian and Zbójnian have complete palynological profiles but, besides lithologic and TL dating, no other investigations have been carried out.

- Two interglacials: Malopolanian and Lubavian are not documented with complete palynological records and they are not documented by other kinds of investigations, so that their ages and stratigraphic positions are speculative.

- Age determinations of a number of interglacial sections are based mainly on palaeobotanic studies and TL datings.

In this situation it is necessary to select the stratotype sections for individual interglacials and to perform additional multidisciplinary investigations.

\section{References}

Ber, A., 1996. Geological situation of Augustovian (Pastonian) interglacial lake sediments at Szczebra near Augustów and Mazovian interglacial organogenic sediments at Krzyżewo. Biuletyn Państwowego Instytutu Geologicznego 373: 35-48.

Ber, A., 2000. Pleistocene of north-eastern Poland and neighbouring areas against crystalline and sedimentary basement. Prace Państwowego Instytutu Geologicznego 170: 89 pp.

Ber, A., Janczyk - Kopikowa, Z. \& Krzyszkowski, D., 1998. A new interglacial stage in Poland (Augustovian) and the problem of the age of the oldest Pleistocene till. Quaternary Science Reviews 17: 761 - 773.

Borówko - Dlużakowa, Z., 1967. Palaeobotanical studies of Late Pleistocene deposits (Brörup) in the Konin-Marantów area. Prace Instytutu Geologicznego 48: 81-136.

Borówko - Dlużakowa, Z. \& Halicki, B., 1957. Interglacials of Suwalki Lakeland and neighbouring areas. Acta Geologica Polonica 4: 361-401.

Dqbrowski, M. J., 1967. Pollen analysis of an interstadial profile from Jasionka near Rzeszów. Acta Geologica Polonica 17: 509-520.

Galqzka, D., Marks, L. \& Zabielski, R., 1999. Is a lithostratigraphic correlation of tills useful for the Quaternary stratigraphy of Poland? Przegląd Geologiczny 47, 3: 261-265.

Glazek, J., Kowalski, K., Lindner, L., Mlynarski, M., Stworzewicz, E., Tucholka, P. \& Wysoczański-Minkowicz, T., 1976. Cave deposits at Kozi Grzbiet (Holy Cross Mts, Central Poland) with vertebrate and snail faunas of the Mindelian I / Mindelian II Interglacial and their stratigraphic correlation. Proceedings of the 7th International Speleological Congress: 211-214.

Górska, M., 2003. Petrographic analysis of Scandinavian erratics. In: Harasimiuk, M. \& Terpilowski, S. (eds): Sedimentological analyses of glaciogenic deposits: 23-33.

Janczyk-Kopikowa, Z., 1981. Pollen analysis of the Pleistocene sediments at Kaznów and Krępiec. Biuletyn Instytutu Geologicznego 321: 249-258.
Janczyk-Kopikowa, Z., 1991. Palynostratigraphy of the Pleistocene in Poland and the problem of the age of deposits from Biesiekierz (Central Poland). Annales Universitas Maria Curie-Sklodowska B46: 111-128.

Janczyk-Kopikowa, Z., 1996. Temperate stages of the Mesopleistocene in northeastern Poland. Biuletyn Państwowego Instytutu Geologicznego 373: 49-66.

Janczyk-Kopikowa, Z., 1975. Flora of the Mazovian Interglacial at Ferdynandów. Biuletyn Instytutu Geologicznego 290: 5-96.

Janczyk-Kopikowa, Z., Mojski, J. E. \& Rzechowski, J., 1981. Position of the Ferdynandów Interglacial, Middle Poland, in the Quaternary stratigraphy of the North European Plain. Rept. 6 on the session IGCP Project: 73, 24: 146-162.

Janczyk-Kopikowa, Z. \& Żarski, M., 1995. The Ferdynandów Interglacial at Stanislawice near Kozienice (Central Poland). Acta Palaeobotanica 35: 7-13.

Kacprzak, L., Lisicki, S. \& Winter, H., 2002. Stratigraphical position of the Czarnucha, the Cisów and the Domuraty sections of the Middle and Lower Pleistocene, NE Poland. Field Symposium on Quaternary geology and geodynamics in Belarus. Abstract Volume: 19-21.

Kaczmarska I., 1976. Diatom analysis of Eemian profile in fresh-water at Imbramowice near Wroclaw. Acta Palaeobotanica 17 (2): 3-34.

Kenig, K., 1998. Petrographic foundations of till stratigraphy of northeastern Poland. Biuletyn Państwowego Instytutu Geologicznego 380: 7-99.

Kenig, K., 2003. Petrographic analysis of gravels $(5-10 \mathrm{~mm})$ in tills. In: Harasimiuk, M. \& Terpilowski, S. (eds): Sedimentological analyses of glaciogenic deposits: 33-51.

Khursevich, G., Nita, M., Ber, A., Sanko, A. \& Fedenya, S., 2004. Palaeoenvironmental and climatic changes during the Early Pleistocene recorded in the lacustrine-boggy-fluvial sediments at Komorniki, NE Poland. Reconstruction of Quaternary palaeoclimate and palaeoenvironments and their abrupt changes. 29 September-2 October 2004, Bialowieża, Poland. Abstracts and Field trip Guide-Book: 11-14. Polish Geological Institute. Warsaw.

Krupiński, M.K., 1988. Plant succession of the Mazovian Interglacial age at Biala Podlaska. Przegląd Geologiczny 427 (11): 647-655.

Krupiński, M.K., 1995. Pollen stratigraphy and succession of vegetation during the Mazovian Interglacial based on studies of sediments from Podlasie. Acta Geographica Lodzensis 70: $200 \mathrm{pp}$.

Krupiński, M.K., 2000. Palynostratigraphic correlation of deposits of the Mazovian Interglacial of Poland (in Polish). Prace Państwowego Instytutu Geologicznego 179: 3-61.

Krupiński, M.K. \& Marks, L., 1985. Interglacial lake sediments at Losy, Mazury Lakeland. Bulletin of the Polish Academy of Sciences, Earth Sciences 34: 375-386.

Krupiński, M.K., Lindner, L. \& Turowski W., 1986. Sediments of the Mazovian Interglacial at Biala Podlaska (Eastern Poland). Bulletin of the Polish Academy of Sciences, Earth Sciences 34 (4): 365-373.

Krzyszkowski, D., 1992. The Middle Pleistocene polyinterglacial Czyżów Formation in the Kleszczów Graben (Central Poland): stratigraphy and palaeography. Folia Quaternaria 61-62: 5-58.

Lindner, L., 1982. South-Polish Glaciations (Nidanian, Sanian) in southern Central Poland. Acta Geologica Polonica 32: 163-167.

Lindner, L., 1984. An outline of Pleistocene chronostratigraphy in Poland. Acta Geologica Polonica 34: 27-49. 
Lindner, L. \& Brykczyńska, E., 1980. Organogenic deposits at Zbójno by Przedbórz, western slopes of the Holy Cross Mts, and their bearing on stratigraphy of the Pleistocene of Poland. Acta Geologica Polonica 30: 155-163.

Lindner, L. \& Marciniak, B., 1998. The occurrence of four interglacials younger than the Sanian 2 (Elsterian 2) Glaciation in the Pleistocene of Europe. Acta Geologica Polonica 48: 247-263.

Lindner, L. \& Marks L., 1994. Pleistocene glaciations and interglacials in the Vistula, the Oder, and the Elbe drainage basins (Central European Lowland). Acta Geologica Polonica 4: 153-165.

Lindner, L. \& Marks, L., 1999. New approach to stratigraphy of palaeolake and glacial sediments of the Middle Pleistocene mid-eastern Poland. Geological Quarterly 41 (1): 1-8.

Lindner, L., Gozhik, P., Marciniak, B., Marks, L. \& Yelovicheva, Y., 2004. Main climatic changes in the Quaternary of Poland, Belarus and Ukraine. Geological Quaterly 48, 2: 97-114.

Lisicki, S., 2003a. Ranges of the Scandinavian ice sheet within the Vistula drainage basin according to petrographical studies of tills and correlation with oxygen isotopic stages. Przegląd Geologiczny 51: 217-223.

Lisicki, S., 2003b. Lithotypes and lithostratigraphy of tills of the Pleistocene in the Vistula drainage basin area, Poland. Prace Państwowego Instytutu Geologicznego 177: 105 pp.

Lisicki, S. \& Winter, H., 1999. Mrongovian and Brokian, new stratigraphic units of the Middle Pleistocene in northeastern Poland. Geological Quarterly 43 (1): 9-18.

Makowska, A., 1986. Pleistocene seas in Poland - sediments, age and palaeogeography. Prace Instytutu Geologicznego 120: 1-74.

Makowska, A., 1991. Pleistocene marine deposits and their bearing on the stratigraphy of the Younger Pleistocene in Dolne Powiśle (North Poland). Geological Quarterly 35: 107-118.

Mamakowa, K., 1989. Late Middle Polish Glaciation, Eemian and Early Vistulian vegetation at Imbramowice near Wroclaw and the pollen stratigraphy of this part of the Pleistocene in Poland. Acta Palaeobotanica 29: 11-176.

Marciniak, B., 1998. Diatom stratigraphy of the Mazovian lacustrine sediments in southeastern Poland. Studia Geologica Polonica 113: 7-64.

Marciniak, B., 2003. The first results of the diatom analyses of interglacial lake sediments of the Lower Pleistocene in Poland. (in Polish). I Polish Quaternary Palaeobotanic Conference. Bialowieża, May 22-24, 2003: 36-38.

Marciniak, B. \& Lindner L., 1994. Diatom stratigraphy of the Mazovian (Holstein, Likhvin) interglacial lacustrine sediments at Biala Podlaska (eastern Poland). Proceedings of the 13th Iternational Diatom Symposium, Manatan, Italy, September 1-7, 1994: 531-540.

Marciniak, B. \& Lindner L., 2003. Diatoms and geology of the Ferdynandovian Interglacial lake sediments in Poland (in Polish). Polish Botanical Studies. Guidebook series.

Marks, L., 2000. Outline of most questionable items of the Quaternary stratigraphy in Poland. Lithosphere 12: 28-36.

Marks, L., Lindner, L. \& Nitychoruk, J., 1995. New approach to a stratigraphic position of the Warta stage in Poland. Acta Geographica Lodzensis 68: 135-147.

Nitychoruk, J., 2000. Climate reconstruction from stable isotope composition of the Mazovian Interglacial (Holsteinian) lake sediments in eastern Poland. Acta Geologica Polonica 50, 2: 247-294.
Nitychoruk, J., Ber, A., Hoefs, J., Krzywicki, T., Schneider, J. \& Winter, H., 2000. Interglaziale Klimaschwankungen in Nordost-Polen - Palynologische und isotopengeochemische Untersuchungen an organischen Seesedimenten. Eiszeitalter und Gegenwart 50: 86-94.

Rzechowski, J., 1996. The Ferdynandovian Interglacial and its stratigraphical position in the Middle Pleistocene of Europe. In: Turner, C. (ed.): The Early Middle Pleistocene in Europe. Balkema (Rotterdam-Brookfield): 279-293.

Skompski, S., 2004. Fauna of the Ferdynandów Interglacial at Podgórze B1 near Wyśmierzyce on Pilica River, Central Poland. Przegląd Geologiczny 52 (6): 516-518.

Skompski, S. \& Ber, A., 1999. Interglacial molluscan fauna at Szczebra near Augustów (NE Poland). Przegląd Geologiczny 47: 1006-1012.

Sobolewska, M., 1952. Interglacial at Barkowice Mokre near Sulejów (in Polish). Biuletyn Instytutu Geologicznego 66: 245-284.

Stachowicz-Rybka, R., 2003. Wymowa klimatyczna makroskopowych szczątków roślinnych z profilu Czarnucha (NE Polska) lokalizowanego pomiędzy zlodowaceniami Narwi i Nidy (interglacjal augustowski). I Polish Quaternary Palaeobotanic Conference. Bialowieża 22-24 May, 2003: 51-54.

Środoń, A. \& Golqbowa, M., 1956. Pleistocene flora at Bedlno (in Polish). Biuletyn Instytutu Geologicznego 100: 7-44.

Turner, C., 1996. A brief survey of the Early Middle Pleistocene in Europe. In: Turner, C. (ed.): The Early Middle Pleistocene in Europe. Balkema, (RotterdamBrookfield): 295-318.

West, R.G., 1996. Outline of the stratigraphy and vegetational history of the Cromer Forest-bed Formation. In: Turner, C. (ed.): The Early Middle Pleistocene in Europe, Balkema (Rotterdam-Brookfield): 1-8.

Winter, H., 2001. New profile of Augustowski Interglacial in north-eastern Poland (in Polish). Geneza, litologia i stratygrafia utworów czwartorzę dowych, T. 3, Seria Geograficzna 64: 439-450.

Wozniak, P., 1989. Zbójnian Interglacial in Suwalki Lakeland (in Polish). Kwartalnik Geologiczny, Tom 33, nr. 3/4: 561-572.

Zabielski, R., 1996. Application of a petrographic method to identification of the till floes. Geological Quarterly 40, 2: 238-298.

Zagwijn, W.H., 1992. The begining of the Ice Age in Europe and its major subdivisions. Quaternary Science Reviews 11: 583-591.

Zagwijn, W.H., 1996. The Cromerian Complex Stage of the Netherlands and correlation with other areas in Europe. In: Turner, C. (ed.): The Early Middle Pleistocene in Europe. Balkema (Rotterdam-Brookfield): 145-172.

Zagwijn, W.H. \& De Jong, J., 1984. Die Interglaziale von Bavel und Leerdam und ihre stratigraphische Stellung im niederlandischen Früh-Pleistozän. Mededelingen Rijks Geologische Dienst 37 (3): 155-169. 